\title{
Exposure to domestic violence in women living in Istanbul and Aegean regions: a Turkish sample
}

\author{
Exposição à violência doméstica em mulheres que vivem \\ em Istambul e nas regiões do Egeu: uma amostra turca
}

Ergül Aslan (https://orcid.org/0000-0002-6529-5992) ${ }^{1}$

Gönül Bodur (https://orcid.org/0000-0002-2811-534X) ${ }^{1}$

Nezihe Kizilkaya Beji (https://orcid.org/0000-0002-6254-4412) ${ }^{2}$

Nevzat Alkan (https://orcid.org/0000-0001-7355-5830) ${ }^{3}$

Ömercan Aksoy (https://orcid.org/0000-0003-4344-8190) ${ }^{4}$

${ }^{1}$ Florence Nightingale Faculty of Nursing, Istanbul University-Cerrahpasa. Abide-i Hürriyet Cad. 34381 Şişli Istanbul Turkey. ergul34tr@hotmail.com

${ }^{2}$ Faculty of Health Sciences, Biruni University. Topkap1

Istanbul Turkey.

${ }^{3}$ School of Medicine,

Istanbul University Istanbul.

${ }^{4}$ Institute of Graduate

Education, Istanbul

University. Cerrahpasa

Istanbul Turkey.

\begin{abstract}
Domestic violence (DV) is a serious public health problem in the world. DV against women is also a global problem without cultural, geographic, religious, social, economic or national boundaries. This descriptive cross-sectional study was carried out to determine the situations of DV in women living in Istanbul and the Aegean Region in Turkey. The study population included outpatient clinics of state hospitals both regions. A stratified sampling by age was performed and 1100 women were included into the sample. Data were collected at face-to-face interviews with Domestic Violence Against Women Determination Scale. The mean age of the women living in Istanbul was $41.81 \pm 9.75$ years and Aegean Region was $33.72 \pm 11.38$ years. The prevalence of emotional and financial violence were higher in Istanbul and the Aegean Region. The women living in Istanbul got higher scores for Domestic Violence Against Women Determination Scale. The prevalence of the women reporting to suffer from violence from their spouses was $15.4 \%$ in Istanbul and $14 \%$ in the Aegean Region. While the prevalence of the women suffering from violence was higher in Istanbul, the women in Aegean Region suffered from more severe violence. The violence prevalence was lower among the wives and the husbands with high education levels, employed women and high-income families.
\end{abstract}

Key words Violence, Domestic violence, Women, Turkey
Resumo A violência doméstica (VD) é um grave problema de saúde pública no mundo. VD contra as mulheres também é um problema global sem fronteiras culturais, geográficas, religiosas, sociais, econômicas ou nacionais. Este estudo descritivo transversal foi realizado para determinar as situações de VD em mulheres que vivem em Istambul e na região do Egeu, na Turquia. Foi realizada uma amostragem estratificada por idade e 1.100 mulheres foram incluidas na amostra. Os dados foram coletados em entrevistas presenciais com a Escala de Determinação de Violência Doméstica Contra a Mulher. A idade média das mulheres que vivem em Istambul foi de $41.81 \pm 9.75$ anos e a região do Egeu foi de $33.72 \pm 11.38$ anos. As prevalências de violência emocional e financeira foram maiores em Istambul e na região do Egeu. A pontuação na Escala de Determinação de Violência Doméstica Contra a Mulher foi mais elevada entre as mulheres que vivem em Istambul. A prevalência das mulheres que relatam sofrer violência de seus cônjuges foi de $15.4 \%$ em Istambul e 14\% na região do Egeu. Embora a prevalência das mulheres que sofrem de violência tenha sido maior em Istambul, as da região do Egeu sofreram de violência mais grave. A prevalência da violência foi menor entre as esposas e os maridos com altos níveis de escolaridade, mulheres empregadas e famílias de alta renda.

Palavras-chave Violência, Violência doméstica, Mulheres, Turquia 


\section{Introduction}

Violence affects lives of millions of people worldwide, across all socioeconomic and educational classes. One of the commonest terms used to describe partner violence is domestic violence (DV). DV is an important public health problem worldwide. DV against women is also a problem encountered throughout the world without having cultural, geographic, religious, social, economic or national boundaries ${ }^{1}$.

When violence occurs at home, it is called DV and is defined by the World Health Organization ${ }^{2}$ as "psychological/emotional, physical, or sexual violence; or threats of physical or sexual violence that are performed on a woman by a family member such as an intimate male partner, marital/cohabiting partner, parents, siblings, or a person very well known within the family or a significant other (i.e. former partner)"3. The incidence of violence, including sexual and domestic abuse against women and girls, varies widely across the population in Turkey. According to the Republic of Turkey Prime Ministry General Directorate on the Status of Women 2008 Survey, the prevalence of DV at some point of women's life from their childhood to time of violence was 39\%. Types of abuse were defined as in the following: (1) Verbal violence refers to using degrading sentences, blaming, swearing, humiliating, insulting and shouting loudly; (2) Physical violence refers to slapping, hitting, pushing, breaking bones, hitting against a wall, tearing hair, kicking, pulling out a knife, injuring and killing; (3) Economic violence means not taking care of expenses, not letting women work, taking money from working women and controlling assets/possessions of women; (4) Emotional violence means cutting direct communication with the spouse, not talking to women, souring, preventing women from expressing themselves and explaining their opinions and ideas, preventing them from seeing their families; (5) Sexual violence means raping, forcing women to a sexual act which they cannot accept, having incestuous relationships, using sexual implications and saying words with sexual content $t^{4}$.

The United Nations defines the violence against women as "any act of gender-based violence that results in or is likely to result in physi$\mathrm{cal}$, sexual or mental harm or suffering to women, including threats of such acts as coercion or arbitrary deprivation of liberty, whether occurring in public or in private life"s. DV against women is still a source of a high public health concern, especially as it continues to be accepted as "normal" within many societies ${ }^{6,7}$. The prevalence of the violence is higher in developing countries than in developed countries. The prevalence of the women exposed to violence by their husbands is $45 \%$ in India, $47 \%$ in Philippines and $52 \%$ in Kenya ${ }^{8}$. In Arab and Islamic countries, DV is not yet considered a major concern, although its prevalence is quite high. On the other hand, studies estimate that $20 \%-50 \%$ of women have experienced physical violence at the hands of an intimate partner or a family member, ${ }^{910}$. In a study conducted in 11 countries by the WHO, the prevalence of DV throughout a lifetime was found to range from $4 \%$ to $54 \%$ and range between $32.9 \%$ and $61.4 \%$ in Turkey ${ }^{11,12}$.

Exposure to violence early in life can contribute to subsequent poor health, alcohol dependence and conjugal violence ${ }^{13}$. Similarly, experiences of violence across the lifespan are associated with poorer mental and physical well-being ${ }^{14}$. Moreover, women who have recently experienced severe episodes of violence generally experience high levels of distress ${ }^{15}$. Female survivors of intimate partner violence who seek advocacy support report higher levels of abuse and depression than the general population ${ }^{16}$ when they first contact services $^{17,18}$.

There are several factors which may be associated with DV against women and which can be classified into individual factors, the factors that may be relevant to the relationship and those relevant to intimates and social norms. The factors associated with DV against women include education and economic freedom of women, presence of social support, and history of DV during childhood. The factors related to men include communication with their wives, the male-dominated society, the physically stronger nature of men, presence of alcohol or drug use, unsatisfactory income levels, and witnessing DV against their mothers during childhood ${ }^{19,20}$. At this point, healthcare providers should understand the abovementioned complex issues involved in DV and should be capable of assessing life-threatening situations and mental health conditions of women exposed to $\mathrm{DV}^{21}$. Protection and promotion of women's health are very important for public health. Health professionals, especially nurses and midwives have undeniable roles in health protection and promotion in women exposed to violence. However, international health institutions mention that physicians and health workers are generally unaware of this problem and do not care about these patients ${ }^{22,23}$. 
DV against women is an important problem in Turkey as in other parts of the world. Patriarchal family structures and traditional norms and values are important elements that affect the role of women in Turkey. Externally motivated explanations for violence are most commonly made via sociobiological, social educational, subcultural and patriarchal theories ${ }^{24,25}$.

Istanbul is a metropolis to which a high number of people from all parts of the country including north, east and south regions migrate and where people with different sociodemographic characteristics reside. Due to the large area it occupies and the high population it harbors, it is considered as a region. The Aegean Region is located in the west of Turkey and the second most crowded region of the country. Education and socio-cultural status of the people in the Aegean region are higher than those of the overall Turkish population.

This study was performed to determine the situations of DV in women living in Istanbul and the Aegean Region in Turkey.

\section{Methodology}

The study had a cross-sectional descriptive design. It was conducted in large scale state hospitals (TUIK 2012) in Istanbul and the Aegean Region (including Aydin, Denizli and Kütahya provinces), located in the western part of Turkey. The sample was formed according to Statistical Region Units Classification of Turkey (NUTS-3) from the age groups like 20-29 years, 30-39 years, 40-49 years, 50-59 years and 60 years and more.

The sample size was calculated based on $95 \%$ confidence interval $(\alpha=0.05)$ and probability of suffering from violence $(\mathrm{p}=0.40)^{26}$ and in proportion to the number of married women in the study population. It was determined that $323 \mathrm{fe}$ males should be included from each region according to current population ratios.

The inclusion criteria for the participants were as follows: (1) not having any mental problems, (2) being literate, being married and living with spouses and (3) volunteering to participate in the study.

Large scale state hospitals were selected for data collection, and gynecology and internal medicine outpatient clinics in these hospitals were preferred as the number of female patients presenting to these outpatient clinics was high. The participants were informed about the study by the researchers, their verbal consent was ob- tained and data was collected through face to face interviews from the women who agreed to participate in the study. The researchers supplied the data collection tools and the participants completed the scale in an appropriate environment in a silent room provided by the researchers. It took 10 minutes for the participants to complete the tools by using a pencil. Two tools were used for data collection. One of them was a personal characteristics form prepared by the researchers and composed of 20 questions about age, education, financial status, employment, family structure, age at marriage, number of children, habits and chronic diseases of the participants and their spouses. The other data collection tool was Domestic Violence Against Women Determination Scale, including 44 questions.

Domestic Violence Against Women Determination Scale was developed by Yanikkerem and Saruhan in $2005^{27}$. The scale included 44 questions about exposure to DV. It is a five-point Likert scale; 1 corresponding to never, 2 rarely (once), 3 sometimes (a few times), 4 often (many times) and 5 always. Higher scores indicate more frequent exposure to violence. The highest and the lowest scores for the scale are 220 and 44 respectively ${ }^{27}$. The content validity of Domestic Violence Against Women Determination Scale Short Form was tested. An item pool was created to assess the content validity and three experts were requested to present their opinions about utility, intelligibility and severity of the items. Item-total correlation coefficients of 44 items of Domestic Violence Against Women Determination Scale-Short Form related to item analysis of the scale (Spearman Correlation) ranged between 0.25 and 0.67 and were positive and statistically significant.

Correlations between item-total subscale scores were calculated; item total score correlation coefficients for each subscale (Spearman Correlation) were between 0.41 and 0.82 , and statistically significant $(r=0.41-0.82$ for physical violence; $r=0.56-0.72$ for economic violence; $r$ $=0.47-0.71$ for emotional violence; $r=0.51-0.74$ for verbal violence; $r=0.57-0.80$ for sexual violence). When correlations of the scores for each subscale with the total score for the scale were analyzed so as to see the concordance of each subscale with the scale, correlation coefficients were found to range between 0.74 and 0.92 and positive and statistically significant. Internal consistency analysis showed that Cronbach's alpha coefficient of subdimensions varied between 0.75 and 0.85 ( $\mathrm{a}=0.76$ for physical violence; $\mathrm{a}=$ 
0.75 for economic violence; $\mathrm{a}=0.85$ for emotional violence; $\mathrm{a}=0.84$ for verbal violence; $\mathrm{a}=0.79$ for sexual violence), and internal consistency of the total scale was very high (Cronbach alpha $=0.93$ ). When each item was excluded, internal consistency coefficient did not change.

The study population included 1728 women. Three-hundred and twenty-five women, of whom 276 were from Istanbul and 49 women were from the Aegean Region, declined to participate in the study. Three hundred and three women, of whom 264 were from Istanbul and 39 were from the Aegean Region, were excluded from the study because they did not meet the criteria (widow / single). The study was conducted on a total of 1100 women, of whom 482 were from Istanbul and 618 were from the Aegean Region.

Written consent was taken from all the institutions where data were collected and ethical approval was obtained from Istanbul University Faculty of Medicine Ethics Committee in order to conduct the study.

Data were analyzed with descriptive statistics including percentage, mean and standard deviation. Mann Whitney U test, One-way ANOVA and Chi-square test were utilized for comparisons. Statistical Package Program for Social sciences version 21 was used for data analyses. Statistical significance was set at $\mathrm{p}<0.05$.

\section{Results}

Almost all the women living in Istanbul and Aegean regions had their first marriages and their husbands were employed. Socio-demographic characteristics of all the participants are presented in Table 1.

Considering women's general health characteristics, $61 \%$ of the women living in Istanbul and $38.7 \%$ of the women living in the Aegean Region had diabetes, hypertension and chronic health problems such as heart disease (Table 2). Twenty-six-point six percent of the women in Istanbul and $22.2 \%$ of the women in the Aegean Region were smokers. The mean body mass index was 26.82 \pm 5.24 in Istanbul and 25.15 \pm 5.06 in the Aegean Region.

Twenty-eight percent of the women in Istanbul $(n=135)$ and $11.5 \%$ of the women in the Aegean Region $(n=71)$ were on the postmenopausal period. The women in both regions had menopause for about 7 years. The mean age at menopause was $45.38 \pm 6.93$ years in Istanbul $(\mathrm{n}=51)$ and $47.77 \pm 4.94$ years in the Aegean Region $(n=57)$ without a significant difference $(\mathrm{MwU}=1195.5 ; \mathrm{p}=0.111)$.

The most frequently reported types of physical violence were beating at $18.5 \%$, damaging things while arguing at $12.6 \%$ and slapping at $9.4 \%$. The most frequent types of economic violence were spouses' controlling all assets and bank accounts of women at $47.8 \%$, lack of permission for working at $42.1 \%$ and spouses' managing all money related activities at $37.6 \%$. The most frequent types of emotional violence were fulfilling spouses' requests despite not wanting to do so at $38.6 \%$, spouses' making decisions about important issues at $38.4 \%$, spouses' not talking unless it was necessary at $29.2 \%$ and spouses' interference with their wives' behavior outside home at $27.9 \%$. The most frequent types of verbal violence were shouting at $44 \%$, criticizing women's behavior at $42.6 \%$ and cursing and insulting at $18.1 \%$. The most frequent types of sexual violence were forcing to have an intercourse at $16.9 \%$, lack of respect for women's opinions about sexuality at $12.7 \%$, wanting to have an intercourse after an argument at $16.9 \%$ and insisting on an intercourse when the women were ill at $10.8 \%$.

Ten-point two percent of the women in Istanbul and $7.7 \%$ of the women in the Aegean Region reported that their children were subjected to violence by their husbands. Fifty-two-point nine percent of the women in Istanbul and $49.1 \%$ of the women in the Aegean Region reported that they witnessed violence against women/children in their surroundings. Twenty-two percent of the women in Istanbul and $13.1 \%$ of the women in the Aegean Region were exposed to a kind of violence during their childhood with a statistically significant difference between the regions ( $p<$ 0.001 ). Women in both regions were subjected to the violence by their father or mother when they were children.

As shown in Figure 1, 15.4\% of the women in Istanbul and 14\% of the women in the Aegean Region were exposed to violence by their spouses. The prevalence of exposure to violence was significantly higher in the women living in Istanbul $\left(\mathrm{x}^{2}=7.92 ; \mathrm{df}=2 \mathrm{p}=0.019\right)$.

The mean score for violence was $57.95 \pm$ 14.35 in Istanbul and $60.99 \pm 13.14$ in the Aegean Region with a statistically significant difference $(\mathrm{MwU} \mathrm{z}=-6.38 \mathrm{p}<0.001)$. Although the prevalence of exposure to violence was higher in Istanbul, the women in the Aegean Region got significantly higher scores for violence severity. 
Table 1. The socio-demographic characteristics of the women living in Istanbul and the Aegean Region (N $=1100)$.

\begin{tabular}{|c|c|c|c|c|}
\hline & \multicolumn{2}{|c|}{ Istanbul } & \multicolumn{2}{|c|}{$\begin{array}{l}\text { Aegean } \\
\text { Region }\end{array}$} \\
\hline & $\mathbf{n}$ & $\%$ & $\mathbf{n}$ & $\%$ \\
\hline \multicolumn{5}{|l|}{$\begin{array}{l}\text { Woman's education } \\
\text { level }\end{array}$} \\
\hline Primary $\downarrow$ & 111 & 23.0 & 58 & 9.4 \\
\hline Primary & 169 & 35.1 & 393 & 63.6 \\
\hline Highschool & 104 & 21.6 & 100 & 16.2 \\
\hline University and $\uparrow$ & 98 & 20.3 & 67 & 10.8 \\
\hline \multicolumn{5}{|l|}{$\begin{array}{l}\text { Husband's education } \\
\text { level }\end{array}$} \\
\hline Primary $\downarrow$ & 52 & 10.8 & 28 & 4.5 \\
\hline Primary & 125 & 25.9 & 324 & 52.4 \\
\hline Highschool & 142 & 29.5 & 152 & 24.6 \\
\hline University and $\uparrow$ & 163 & 33.8 & 114 & 18.4 \\
\hline \multicolumn{5}{|l|}{ Woman's work status } \\
\hline Housewife & 305 & 63.3 & 477 & 77.2 \\
\hline Employed & 177 & 36.7 & 141 & 22.8 \\
\hline \multicolumn{5}{|l|}{$\begin{array}{l}\text { Income level of the } \\
\text { family }\end{array}$} \\
\hline Minimum & 113 & 23.4 & 119 & 19.3 \\
\hline Middle & 297 & 61.7 & 289 & 46.7 \\
\hline $\begin{array}{l}\text { Good and very } \\
\text { good }\end{array}$ & 72 & 14.9 & 210 & 34.0 \\
\hline \multicolumn{5}{|l|}{ Family type } \\
\hline Nuclear family & 404 & 83.8 & 480 & 77.7 \\
\hline \multirow[t]{2}{*}{ Extended family } & 78 & 16.2 & 138 & 22.3 \\
\hline & \multicolumn{2}{|c|}{ Mean \pm SD } & \multicolumn{2}{|c|}{ Mean \pm SD } \\
\hline Woman's age & \multicolumn{2}{|c|}{$41.81 \pm 9.75$} & \multicolumn{2}{|c|}{$33.72 \pm 11.38$} \\
\hline Husband's age & \multicolumn{2}{|c|}{$46.22 \pm 10.33$} & \multicolumn{2}{|c|}{$38.08 \pm 12.14$} \\
\hline Woman's marriage age & \multicolumn{2}{|c|}{$21.22 \pm 4.84$} & \multicolumn{2}{|c|}{$20.03 \pm 3.66$} \\
\hline Number of births & \multicolumn{2}{|c|}{$2.20 \pm 1.46$} & \multicolumn{2}{|c|}{$1.94 \pm 1.28$} \\
\hline
\end{tabular}

As presented in Figure 2, there was no significant difference in physical, verbal and sexual violence scores between the women in Istanbul and in the Aegean Region $(\mathrm{p}=0.550 ; \mathrm{p}=0.439 ; \mathrm{p}=0.793$ ). However, statistically significant differences were identified between the regions in terms of the total score for exposure to economic and emotional violence $(\mathrm{p}=0.001 ; \mathrm{p}=0.001)$.

The women and their husbands with university education and/or a higher level of education, the employed women and the women with a high or very high income had significantly lower mean scores for violence $(\mathrm{p}=0.001 ; \mathrm{p}=0.001$ ) The women with chronic diseases were more frequently exposed to violence and the prevalence of the women with depression exposed to violence was significantly higher (Table 2).

\section{Discussion}

Violence against women is a global health problem and common in all cultures. In Turkey, it is considered as a normal phenomenon and legitimization of violence within the family causes repetition, hiding or ignoring of violence. Violence against women needs to be studied and discussed so that people's viewpoints about it can be changed. According to a WHO report, the prevalence of physical and sexual violence exerted by the spouse ranges between 15\% (Japan) and 70\% (Ethiopia/Peru $)^{5}$. In the present study, violence against women was higher in Istanbul, which is a metropolitan area. It is ascribed with the cosmopolitan and migration-prone nature of Istanbul Region. The incidence and the prevalence of violence against women are increasing globally regardless of location, geographic boundaries, level of development and education. In studies supportive of this idea, the DV prevalence was found to be $21.2 \%$ among married women in India ${ }^{28}$, $20 \%$ in Saudi Arabia and was 83\% in Iran ${ }^{29,30}$.

The most common type of violence against women who participated in the current study was emotional violence, which ranked first in both Istanbul and the Aegean Region. The emotional violence score was 19.3 in Istanbul Region and 20.8 in the Aegean Region. Consistent with the present study, some studies showed that emotional violence was the most frequent. The emotional violence prevalence was $85 \%$ in Nigeria $^{31}$, $69 \%$ in Saudi Arabia ${ }^{29}, 44 \%$ in $\operatorname{Iran}^{32}$ and $31 \%$ in $\mathrm{Nepal}^{33}$. In a study conducted in India, emotional violence ranked second ${ }^{28}$.

Concerning the socio-cultural viewpoint, violence against women is regarded as legitimate in male-dominant countries governed by Islamic regime where religion supports violence against women. It is known that Turkey also has a social structure dominated by men in spite of not having an Islamic regime, and there are men who exert emotional violence against women using abovementioned religious elements. Women's thinking that they deserve the emotional violence they are exposed to and accepting this violence make it difficult to reach them. The present study showed that economic violence was the third most common type of violence in Istanbul Region and the second most common type of violence in the Aegean Region. It is accepted that there are 1.3 billion poor people in the world and women are considered to account for $70 \%$ of poor people ${ }^{34}$. Low income levels, dominating people's lives greatly in the families with low 
Table 2. The Distribution of Violence Scores by Some Socio-Demographic Characteristics.

\begin{tabular}{|c|c|c|c|c|}
\hline \multirow{2}{*}{\multicolumn{2}{|c|}{ Socio-Demographic Characteristics }} & \multirow{3}{*}{$\begin{array}{c}\text { Total Violence Score } \\
\text { Mean } \pm \text { SD } \\
63.11 \pm 16.29\end{array}$} & \multirow{2}{*}{\multicolumn{2}{|c|}{ Test }} \\
\hline & & & & \\
\hline \multirow{4}{*}{$\begin{array}{l}\text { Woman's educational } \\
\text { level }\end{array}$} & Primary $\downarrow$ & & $F=26.25$ & $\mathrm{p}<0.001$ \\
\hline & Primary & $61.85 \pm 13.30$ & & \\
\hline & Highschool & $55.63 \pm 12.39$ & & \\
\hline & University and $\uparrow$ & $53.66 \pm 10.80$ & & \\
\hline \multirow{4}{*}{$\begin{array}{l}\text { Husband's education } \\
\text { level }\end{array}$} & Primary $\downarrow$ & $62.24 \pm 13.64$ & $F=22.63$ & $\mathrm{p}<0.001$ \\
\hline & Primary & $62.95 \pm 14.14$ & & \\
\hline & Highschool & $58.45 \pm 13.76$ & & \\
\hline & University and $\uparrow$ & $54.88 \pm 11.43$ & & \\
\hline \multirow[t]{2}{*}{ Woman's work status } & Housewife & $61.71 \pm 13.66$ & $\mathrm{z}=6.58$ & $\mathrm{p}=0.010$ \\
\hline & Employed & $54.63 \pm 12.68$ & & \\
\hline \multirow{3}{*}{$\begin{array}{l}\text { Income level of the } \\
\text { family }\end{array}$} & Minimum & $63.57 \pm 15.71$ & $\mathrm{~F}=18.34$ & $\mathrm{p}<0.001$ \\
\hline & Middle & $59.73 \pm 13.59$ & & \\
\hline & High & $56.30 \pm 11.36$ & & \\
\hline \multirow[t]{2}{*}{ Hypertension } & Yes & $61.98 \pm 16.89$ & $7=-150$ & $n=0131$ \\
\hline & No & $59.22 \pm 13.05$ & $Z=-1,50$ & $p=0.131$ \\
\hline \multirow[t]{2}{*}{ Diabetes } & Yes & $61.17 \pm 13.89$ & $7-86$ & $n-0307$ \\
\hline & No & $59.59 \pm 13.76$ & $Z=-, 86$ & $\mathrm{p}=0.392$ \\
\hline \multirow[t]{2}{*}{ Stomach problems } & Yes & $62.25 \pm 17.72$ & & \\
\hline & No & $59.37 \pm 13.22$ & $\mathrm{z}=-1,10$ & $\mathrm{p}=0.2 / 2$ \\
\hline \multirow[t]{2}{*}{ Depression } & Yes & $65.47 \pm 16.24$ & & \\
\hline & No & $59.32 \pm 13.53$ & $\mathrm{z}=-3,31$ & $\mathrm{p}=0.001$ \\
\hline
\end{tabular}

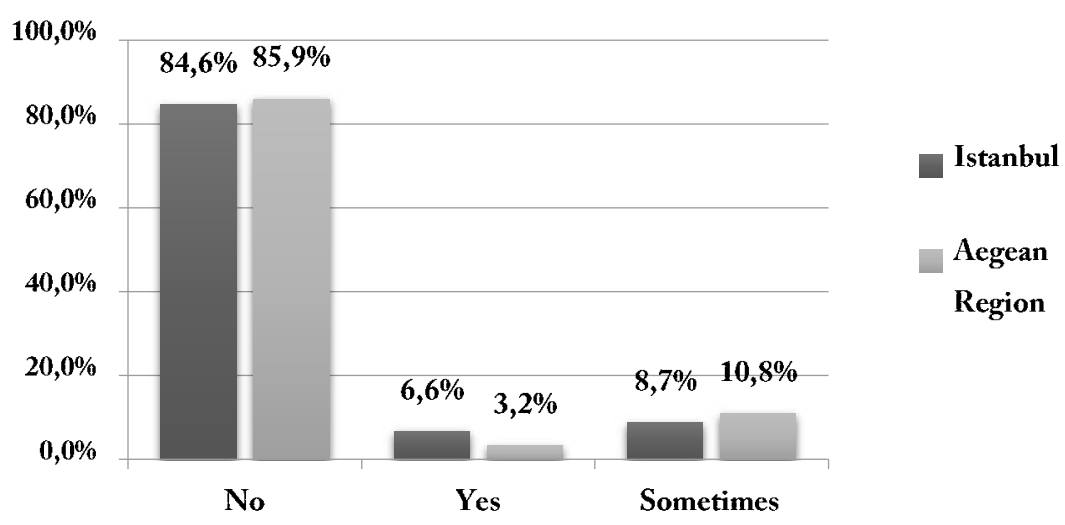

Figure 1. The Percentages of the Women Exposed to Violence by their Spouses.

socio-economic status, increase violence and decrease psychical safety ${ }^{35}$. The studies supporting this idea were conducted in the countries where women participate in labor force less. It has been shown that low socio-economic status increases the violence risk between spouses ${ }^{36}$. Economic problems have been the most prevalent cause of arguments in families ${ }^{37}$. Policies that prevent women from participating in labor force, mobbing at work, husbands' not allowing their wives to work, women's fulfillment of all responsibilities related to child care and women's not having 


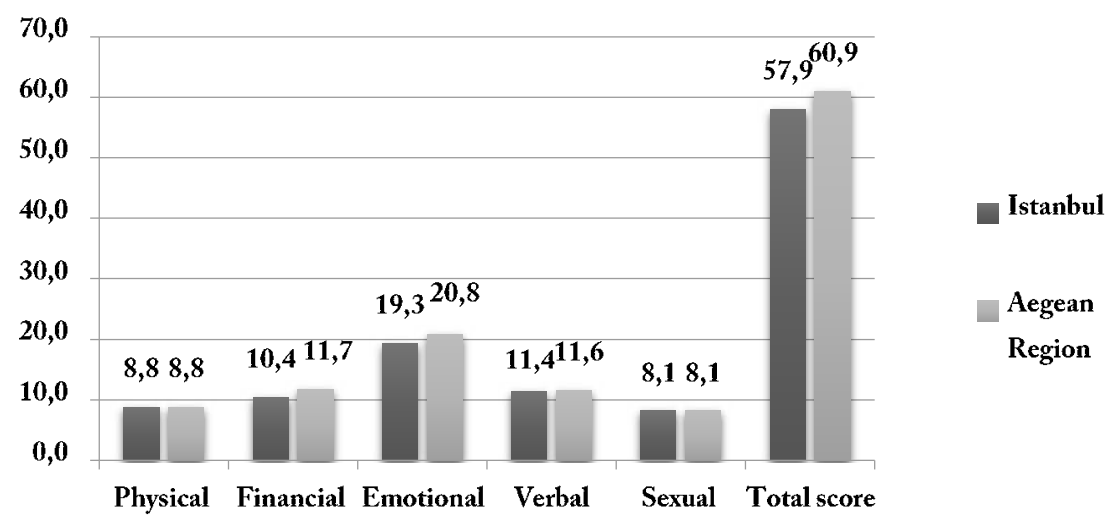

Figure 2. Comparison of Istanbul and the Aegean Region in terms of Scores for Types of Violence.

economic freedom due to such factors as lack of access to education can lead to an increase in economic violence ${ }^{38}$.

In the present study, the sexual violence score in both Istanbul and the Aegean Region was found to be 8.1 , which was statistically significant. It is the least common form of violence in both regions. In line with the present study, a study performed on women in Turkey, sexual violence was shown to be the least common form of violence $(6.9 \%)^{39}$. It can be attributed to the tendency to avoid revealing forced intercourse or not to regard it as sexual violence. In a study conducted in the USA, the overall baseline prevalence of emotional abuse, physical violence, forced sex, and experiencing two or more types of violence in the past 6 months were $31 \%, 19 \%$, $7 \%$, and $17 \%$ respectively ${ }^{40}$. In a study on Nepalese women, sexual violence was the third most common type of violence at the rate of $6.8 \%{ }^{33}$. However, a striking finding of a study in Iran revealed that $73.4 \%$ of the women experienced sexual violence ${ }^{30}$.

In the present study, the physical violence score was 8.8 in the women both in Istanbul and the Aegean Region without a significant difference. This score was lower than economic, emotional and verbal violence scores. Most of the women participating in this study were housewives and had an education level lower than high school. This group can be considered as economically dependent on their spouses and unable to express the violence by their spouses. In a study conducted in Kenya, $42 \%$ of the women reported that they were beaten regularly by their husbands ${ }^{41}$. In a study conducted in East Sudan, the prevalence of physical violence against women was found to be $33.5 \%{ }^{42}$.

Concerning DV in European countries, it has been reported that $12.9 \%$ of the women in Spain were exposed to physical violence by their spouses and that $16.2 \%$ were exposed to sexual abuse by their spouses ${ }^{2}$. As for developed countries, one study showed that $67 \%$ of the women in Japan and $27 \%$ of the women in Washington were exposed to physical violence ${ }^{43,44}$. In Arab countries, DV is not regarded as a social problem, but as a familial problem and it is thought that it can be solved by correcting women's mistakes. A study from Egypt, Palestine, Israel and Tunisia revealed that one in three women is beaten by their spouses'

Although the prevalence of exposure to violence was higher in Istanbul, the women in the Aegean Region had a higher score for violence. This can be attributed to the fact that the traditional family structure had a stronger influence and that women could not share familial problems in the Aegean Region. In addition, the women in the Aegean Region were at disadvantage due to their poorer socioeconomic status. This might have prevented them from expressing their experiences of violence.

In light of the results of this study, although violence against women is a widely studied subject, it still needs to be examined more extensively by gathering more local data. When Istanbul and the Aegean Region are compared, the former constitutes a more multicultural structure since it is a migration-receiving metropolitan. In addition, data were obtained by using a questionnaire in the present study. Further studies supported by qualitative research methods on disadvan- 
taged groups can provide stronger evidence directed towards preventing violence.

In conclusion, the women in Istanbul and those in the Aegean Region were alike in terms of exposure to violence. However, while the prevalence of exposure to violence was higher in Istanbul, the scores for the violence scale indicated that the women in the Aegean Region were found to experience more severe violence. The most common violence in both regions was emotional, financial and verbal violence. Besides, violence committed by the spouses of the women was affected by education, women's employment and family income.

It can be suggested that changes and cultural elements should be taken into consideration and that positive effects of the media should be utilized in order to decrease violence against women and to increase awareness and sensitivity in the regions where the study was conducted. Also, the number of centers which can provide counseling on violence should be increased and practices directed towards preventing violence should be incorporated into primary health care services.

\section{Limitations of the study}

Although the present study was conducted on a large sample in two different regions, it was not community-based, which can be considered as a limitation.

\section{Collaborations}

E Aslan, G Bodur, NK Beji, N Alkan and Ö Aksoy approved the content of the manuscript and have contributed significantly to research involved/ the writing of the manuscript.

\section{Acknowledgement}

We would like to thank Fatma Balci, Hulya Birgun, Kubra Incirkus, Ozlem Kasal, Havva Yilmaz and Menekse Dogac for their contribution in data collection. 


\section{References}

1. Chitashvili M, Javakhishvili N, Arutiunov L, Tsuladze L, Chachanidze S. National research on domestic violence against women in Georgia. 2010. [cited $2017 \mathrm{Feb}$ 3]. Available from: http://www2 ohchr org/english/ bodies/cedaw/docs/AdvanceVersions/GeorgiaAnnexX pdf.

2. World Health Organization (WHO). World report on violence and health. Geneva: WHO; 2002.

3. Krug EG, Mercy JA, Dahlberg LL, Zwim AB. The world report on violence and health. Lancet 2002; 360(9339):1083-1088.

4. The Republic of Turkey. Prime Ministry General Directorate on the Status of Women. Domestic Violence Against Women in Turkey. 2008; Ankara. [cited 2017 Apr 3]. Available from: from http://www.hips. hacettepe.edu.tr/eng/dokumanlar/2008TDVAWMain_Report.pdf

5. World Health Organization (WHO). Violence against women: fact sheet No:239. 2013; [cited 2017 Apr 3]. Available from: http://www who int/mediacentre/ factsheets/fs239/en/

6. Berry DB. The domestic violence sourcebook. Los Angeles: NTC Business Books; 1998.

7. Ilika AL. Women's perception of partner violence in a rural Igbo community. Afr J Reprod Health 2005; 9(3):77-88.

8. United Nations Educational, Scientific and Cultural Organization (UNESCO). Domestic violence against women and girls. Florence: Innocenti Research Centre; 2000.

9. Douki S, Nacef F, Belhadj A, Bouasker A, Ghachem R. Violence Against Women in Arab and Islamic Countries. Arch Women Mental Health 2003; 6(3):165-171.

10. Kocacik F, Dogan O. Domestic violence against women in Sivas, Turkey: Survey Study. Journal of Public Health 2006; 47(5):742-749.

11. Nacar M, Baykan Z, Poyrazoglu S, Cetinkaya F. Domestic violence against women in two primary health care centers in Kayseri TAF Prev Med Bull 2009; 8(2):131-138.

12. Ozyurt BC, Deveci A. The relationship between domestic violence and the prevalence of depressive symptoms in married women between 15 and 49 years of age in a rural area of Manisa, Turkey. Turkish J Psychiatry 2011; 22(1):10-16.

13. Brozowski K, Hall DR. Aging and risk: Physical and sexual abuse of elders. Canada J Interpers Violence 2010; 25(7):1183-1199.

14. Roustit C, Renahy E, Guernec G, Lesieur S, Parizot I, Chauvin P. Exposure to interparental violence and psychosocial maladjustment in the adult life course: Advocacy for early prevention. J Epidemiol Community Health 2009; 63(7):563-568.

15. Hegarty KL, O’Doherty LJ, Chondros P, Valpied J, Taft AJ, Astbury J, Brown SJ, Gold L, Taket A, Feder GS, Gunn JM. Effect of type and severity of intimate partner violence on women's health and service use: findings from a primary care trial of women afraid of their partners. J Interpers Violence 2013; 28(2):273-294.

16. Coker A, Smith P, Whitaker D, Le B, Crawford T, Flerx V. Effect of an in-clinic IPV advocate intervention to increase help seeking, reduce violence, and improve well-being. Violence Against Women 2012; 18(1):1831 .
17. Tiwari A, Fong D, Yuen K, Yuk H, Pang P, Humphreys J. Effect of an advocacy intervention on mental health in Chinese women survivors of intimate partner violence: a randomized controlled trial. JAMA 2010; 304(5):536-543.

18. Sullivan C, Tan C, Basta J, Rumptz M, Davidson W. An advocacy intervention program for women with abusive partners: initial evaluation. Am J Community Psychol 1992; 20(3):309-32.

19. United Nations Children's Fund (UNICEF). Domestic violence against women and girls. Innocenti Digest 2000; 6: 1-30. [cited $2017 \mathrm{Feb} 3$ ]. Available from https://www unicef-irc org/publications/pdf/digest6e pdf.

20. Flury M, Nyberg E, Riecher-Rossler A. Domestic violence against women: Definitions, epidemiology, risk factors and consequences. Swiss Medical Weekly 2010; 140:w13099.

21. Hou W, Wang H, Chung H. Domestic violence against women in Taiwan: Their life-threatening situations, post-traumatic responses, and psycho-physiological symptoms an interview study international. Journal of Nursing Studies 2005; 42(6):629-636.

22. Ergonen AT, Özdemir MH, Cani IO, Sönmez E, Salacin S, Berberoglu E, Demir N. Domestic violence on pregnant women in Turkey. J Forensic Leg Med 2009; 16(3):125-129.

23. Yanikkerem E, Karadas G, Adiguzel B, Sevil U. Domestic violence during pregnancy in Turkey and responsibility of prenatal healthcare providers. Am J Perinatol 2006; 23(2):93-103.

24. Neugebauer R. Research on intergenerational transmission of violence: the next generation. Lancet 2000; 335(9210):1116-1117.

25. Sahin NH, Timur S, Ergin AB, Taşpınar A, Balkaya NA, Çubukçu S. Childhood Trauma, Type of Marriage and Self-Esteem as Correlates of Domestic Violence in Married Women in Turkey. J Fam Viol 2010; 25:661.

26. Karaçam Z, Calıșır H, Dündar E, Altuntaș F, Avcı H Evli kadınların aile içi şiddet görmelerini etkileyen faktörler ve kadınların șiddete ilișkin bazı özellikleri (Factors affecting domestic violence against married women and several characteristics of women related to violence). E. Ü. Hemșirelik Yüksekokulu Dergisi 2006; 22(2):71-88

27. Yanikkerem E, Saruhan A. The investigation on the opinion married women between the age of 15-49 on inner domestic violence and the circumstances they exposed to violence. MN Klinik Bilimler \& Doktor 2005; 11:198-204 (in Turkish).

28. Begum S, Donta Balaiah, Nair Saritha, Prakasam CP Socio-demographic factors associated with domestic violence in urban slums, Mumbai, Maharashtra, India. Indian J Med Res 2015; 141(6):783-788.

29. Barnawi FH. Prevalence and risk factors of domestic violence against women attending a primary care center in Riyadh, Saudi Arabia. J Interpers Violence 2015; 32(8):1171-1186

30. Aghakhani N, Nia HS, Moosavi E, Eftekhari A, Zarei A, Bahrami N, Nikoonejad AR. Study of the types of domestic violence committed against women referred to the legal medical organization in Urmia-Iran. Iran J Psychiatry Behav Sci 2015; 9(4):e2446. 
31. Onigbogi MO, Odeyemi KA, Onigbogi OO. Prevalence and factors associated with intimate partner violence among married women in an urban community in Lagos State Nigeria. Afr J Reprod Health 2015; 19(1):91-100.

32. Jahromi MK, Jamali S, Koshkaki AR, Javadpour S. Prevalence and risk factors of domestic violence against women by their husbands in Iran. Glob J Health Sci 2016; 8(5):175-183.

33. Sapkota D, Bhattarai S, Baral D, Pokharel PK. Domestic violence and its associated factors among married women of a village development committee of rural Nepal. BMC Res Notes 2016; 9:178.

34. United Nations. Human development report. New York: Oxford University Press; 1995.

35. Mcllwaine C, Moser C. Poverty, violence and livelihood security in urban Colombia and Guatemala. Progress in Development Studies 2003; 3(12):113-130.

36. Djikanović B, Wong SL, Jansen HA, Koso S, Simić S, Otasević S, Lagro-Janssen A. Help-seeking behaviour of Serbian women who experienced intimate partner violence. Fam Pract 2011; 9(2):189-195.

37. Ghazizadeh A. Domestic violence: a cross-sectional study in an Iranian city. East Mediterr Health J 2005; 11(5-6):880-887.

38. Ararat M, Alkan S, Bayazıt M, Yüksel A, Budan P. (2014). Domestic Violence Against White-Collar Working Women in Turkey, A Call for Business Action. [cited 2017 Feb 5]. Available from: http://research.sabanciuniv.edu/25972/1/BADV_Report.pdf.

39. Gökler ME, Arslantas D, Unsal A. Prevalence of domestic violence and associated factors among married women in a semi-rural area of western Turkey. Pak J Med Sci 2014; 30(5):1088-1093.

40. Montgomery BE, Rompalo A, Hughes J, Wang J, Haley D, Soto-Torres L, Chege W, Justman J, Kuo I, Golin C, Frew P1, Mannheimer S1, Hodder S. Violence against women in selected areas of the United States. Am J Public Health 2015; 5(10):2156-2166.

41. Heisse L. Violence against women: Global Organization for Change. Thousand Oaks: Sage Publications; 1996.

42. AbdelAziem A, Yassin K, Omer R. Domestic violence against women in Eastern Sudan. BMC Public Health 2014; 14:1136.

43. Abbott J, Johnson R, Koziol-McLain J, Lowenstein SR. Domestic violence against women: Incidence and prevalence in an emergency department population. JAMA 1995; 273(22):1763-1767.

44. Weingourt R, Maruyama T, Sawada I, Yoshino J. Domestic violence and women's mental health in Japan. Int Nurs Rev 2001; 48(2):102-108.

Artigo apresentado em 29/05/2017

Aprovado em 27/11/2017

Versão final apresentada em 29/11/2017 